\title{
弾性表面波の進行波を用いた皮虐感覚ディスプレイ*
}

\author{
高 㟝 正 也*1,*2, 奈 良 高 明*3 \\ 樋口俊 郎*4, 水 野 毅*5
}

\section{A Tactile Display Using Progressive Surface Acoustic Wave}

\author{
Masaya TAKASAKI*6, Takaaki NARA, \\ Toshiro HIGUCHI and Takeshi MIZUNO \\ ${ }^{* 6}$ Department of Mechanical Engineering, Saitama University, \\ 255 Shimo-Okubo, Sakura-ku, Saitama-shi, Saitama, 338-8570 Japan, \\ JST, PRESTO, Interaction and Intelligence
}

\begin{abstract}
A tactile display using progressive surface acoustic wave (SAW) was proposed. A progressive SAW tactile display module was fabricated on trial. The display provides alternative shear forces to an operator's fingertip as stimuli. The forces propagate into the fingertip skin as vibration and are perceived as tactile sensation. To indicate roughness sensation, the display was controlled so that the vibration according to operator's action could be generated. The vibration was measured to indicate validity of the display and its controller. For demonstration, the module was installed on a PC mouse button. Using the mouse, operators could enjoy roughness sensation as if they would rub on a rough solid surface. We also discussed tactile display application for a computer interface. Another controller was built to express screen darkness. While dragging over the screen, the display could provide different roughness according to the darkness under the mouse pointer.
\end{abstract}

Key Words: Human Interface, Tactile Display, Ultrasonic Motor, Surface Acoustic Wave

\section{1. 緒言}

近年,さまざまな作業にコンピュータを用いるよう になり,コンピュータに情報を入力したり,コンピュ 一タから情報を得たりする機会が多くなっている，最 近では Graphical User Interface (GUI)ベースのオぺ レーションシステムが主流となっており, コンピュー タから提示される情報は視覚と聴覚によって認識して いる.ここで, 触覚による情報の提示も行うと，ユー ザが享受できる情報量は増大し，作業効率を向上する ことができると考えられる．また，遠隔地の環境や人 工的に創り出した環境の提示をより現実感のあるもの にできるため, 皮膚感覚の提示は遠隔操作や Virtual Reality(VR)などの分野においても注目されている.

触覚, つまり人間が持つ感覚のうち, 何かに触って いる感覚, 何かを持っている・つかんでいる感覚, 何

* 原稿受付 2006 年1月 26 日.

*1 正員, 埼玉大学工学部（ 338-8570 さいたま市桜区下大久 保 255).

*2 正員, 科学技術振興機構さきがけ(③32-0012 川口市本町 4-1-8).

*3 東京大学大学院情報理工学系研究科( 113-8656 東京都文 京区本郷 7-3-1)

*4 正員, 東京大学大学院工学系研究科.

*5 正員, 埼玉大学工学部.

E-mail : masaya@mech.saitama-u.ac.jp
かをなぞっている感覚といった機械的刺激を感じる感 覚は，二つの種類に大別される。一方は，人間の筋 肉・腱・関節囊などの深部に存在する深部受容器 (proprioceptor)によって受容される「運動感覚」（ま たは「深部感覚」,「力感覚」)であり, 物理形状, 弾力, 抵抗力，重量等を認識する。他方は，皮下組織中の機 械受容器細胞 (mechanoreceptor)によって受容され る「皮膚感覚」であり, 固体表面のざらざら感, 材質 感，摩擦等を認識する感覚である，皮膚感覚には，触 覚, 圧覚, 温度感覚, 痛覚などが含まれるが, 本研究で は触覚のみに注目している。ここでいう「触覚」は狭 義であり，前段のものと区別される．

運動感覚の提示は広く研究が行われており, 製品化 の例も見られる(1). 一方, 触覚に着目した皮膚感覚デ イスプレイの開発においては，さまざまなアクチュエ ー夕を用いたデバイスに関する研究(2) (6) が報告され ているが,これらのアクチュエータにはある程度の体 積を必要とするため, 実用化レベルのデバイスの開発 には至っていない，著者らは皮膚感覚を提示するため の手法として, 弾性表面波 (SAW : surface acoustic wave)の応用に着目した. 弾性表面波振動子は一般に 薄く構成でき (1 mm 以下), 振動分布が振動子の片面 表面にのみ分布しているため，裏面を固定に利用する 
ことが容易である.また, 駆動周波数が一般に数 $\mathrm{MHz}$ 以上と高いため, メカトロニクスに応用した場 合, 応答の速いデバイスを得ることができる。これま でに, 弾性表面波の定在波を利用した皮膚感覚ディス プレイを提案しており, 試作した装置で粗さ感覚を提 示することに成功している(7)(8).

本研究では, 弾性表面波の進行波を用いた皮膚感覚 ディスプレイを提案する.ディスプレイを製作し, 出 力される振動の評価を行った，また，ディスプレイを コンピュータマウスに搭載し, コンピュータインタフ エースとした.このマウスを用いた情報の提示につい ても検討を行った.

\section{2. 原理}

$2 \cdot 1$ 弾性表面波 図1に示すように, 圧電性媒 体の表面に配置されたくし形電極(IDT : interdigital transducer)に交流電圧を印加すると，弾性表面波が 励振され, 図中矢印の向きに伝搬する. 本研究では圧 電性媒体として $\mathrm{LiNbO}_{3} 128^{\circ} \mathrm{Y}$-cut 基板を用いてお り, IDT はアルミニウムの蒸着膜で構成されている. 印加する交流の周波数はIDT の電極ピッチに依存し， 本研究で用いている IDT では $200 \mu \mathrm{m}$ 間隔であり, 駆 動周波数は $9.6 \mathrm{MHz}$ である.

弾性表面波の一種であるレイリー波の進行波の場 合, 弾性体媒体表面では図 2 に示すようにだ円軌道を 描きながら振動している.振動エネルギーの $99 \%$ が 表面から 2 波長以内に分布しており, 弾性体媒体の裏

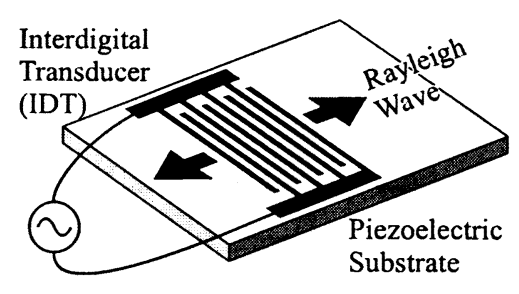

Fig. 1 Excitation of Rayleigh wave

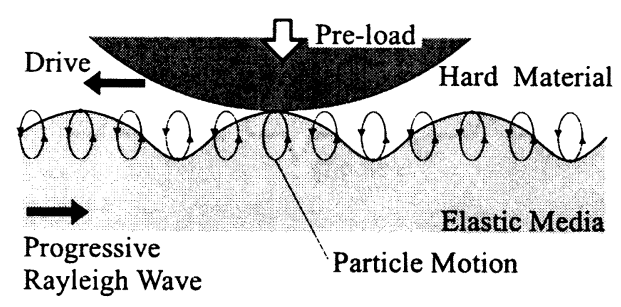

Fig. 2 Particles motion on the surface in the progressive Rayleigh wave and a steel ball driven by the wave
面には振動は分布しない.ゆえに, 振動子裏面を接着 剤で貼り付けるといった固定方法も可能である.

だ円軌道を描きながら振動している表面に, 弾性体 媒体と同程度以上の剛性を持った固体を接触させる と, だ円軌道上側の運動が摩擦力を介して固体に伝達 されるため, 図中矢印の向きに駆動力を得る. 適切な 予圧を与えて接触させることで, レイリー波の伝搬方 向と逆向きの推力を得ることができる.この推力を利 用して, 人の指皮膚表面に機械的刺激を与えて皮膚感 覚ディスプレィを実現するため, ディスプレイ使用者 は自ら指を動かす必要はない. また,この推力のアク チュエータへの応用に関しては, すでに弾性表面波り ニアモータとして報告されている(9)(10).

$2 \cdot 2$ 皮虏感覚ディスプレイ 指である粗さを持 った固体表面をなぞると, 微視的には皮膚の表面が固 体表面の突起との衝突を繰返し, なぞり速度と突起間 隔に応じた周波数の振動が生じ, その振動が皮下組織 内の受容器細胞で知覚され, 皮膚感覚として認識され ていると考えられる. マイスナー小体, パチニ小体な どの受容器が皮下組織に分布しており, それぞれ速度, 加速度を検出していることが知られている. ある固体 表面をなぞったときの感覚を提示するには, なぞり動 作に応じた振動を発生して皮膚に与えることが有効で あると考えられる。

図 3 に弾性表面波皮膚感覚ディスプレイの基本構成 を示す. 2 組の IDT を備えた圧電材料基板表面に, あ る程度剛性を持った物体として, 鋼球を多数分布させ たパッド(ゴム膜に鋼球を接着させたもの)を配置す る.パッドは皮膚感覚ディスプレイ使用者の指と同程 度の大きさであり, 使用者はこの上に指を乗せる.こ のとき, 進行波が励振されている状態では, 前述のと おりパッドに接している皮膚は鋼球越しにせん断力を 受ける. 図 4 に示すように, 2 組の IDT より交互にレ イリー波の進行波を放射することで, パッドに発生す るせん断力を交番力とすることができる、また，レイ リー波の駆動交流電圧を搬送波と考え, 搬送波を On/

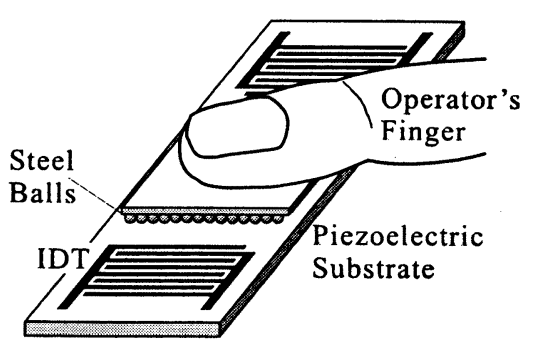

Fig. 3 Basic structure of the SAW tactile display 
Off することで交番力の励振を制御でき，指皮膚が受 ける交番力を時間領域で調整することができる。指で 固体表面をなぞった際に，指皮虔表面で生じる振動と 同じ周波数のせん断力を分布させることで, ある粗さ を持った固体表面をなぞったときの感覚を擬似的に表 現することができる.

図 5 に，製作した皮顱感覚ディスプレイュニットを 示す. $\mathrm{LiNbO}_{3}$ 基板表面に 2 組のIDT が形成され， 中央に鋼球とゴム膜から成るパッドが配されている。 レイリー波の進行波を励振するためには，基板端での 反射を抑制する必要があるため, IDT 背後には吸音材 とそれに結合されたヒートシンクが設置されている. 使用時にはIDT は樹脂製のカバーで保護される。工 ニットは他の機器に装着することが可能である.

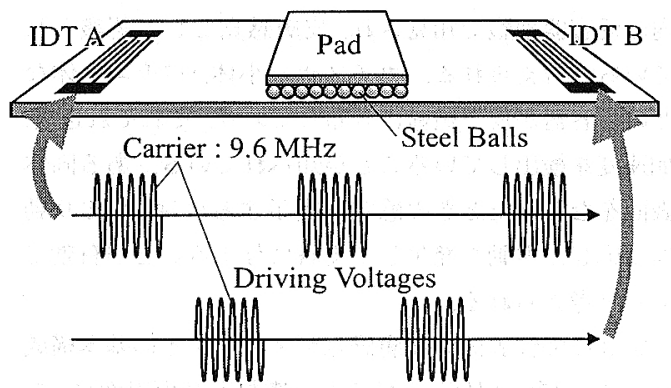

Fig. 4 Excitation of two phases of modulated Rayleigh wave

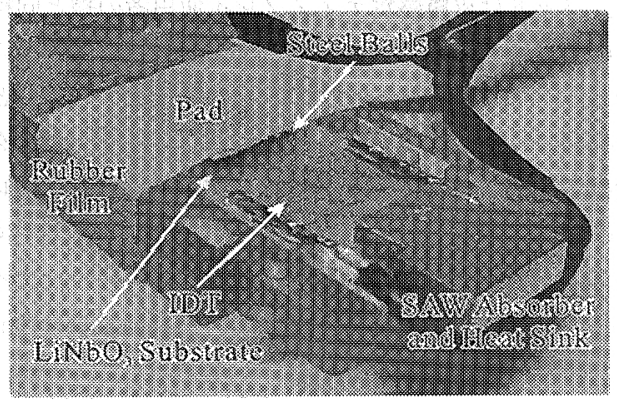

Fig. 5 A passive type SAW tactile display unit the $\mathrm{LiNbO}_{3}$ substrate with the IDT, the steel balls pad and the SAW absorbers with the heat sink)

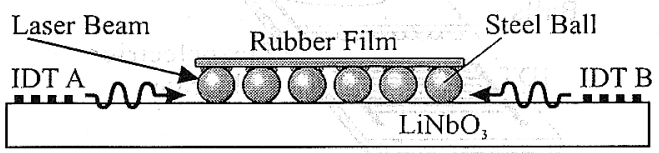

Fig. 6 Measurement of steel ball vibration

\section{3. 振 動 特 性}

皮膚感覚ディスプレイユニットの，パッド部の鋼球 に発生する振動を計測した，図 4 に示すように 2 組の IDT に駆動電圧を印加した状態で，図 6 に示すように レーザドップラー振動速度計でゴム膜下の鋼球の振動 速度を計測した。目的とする周波数を $50 \sim 400 \mathrm{~Hz}$ に

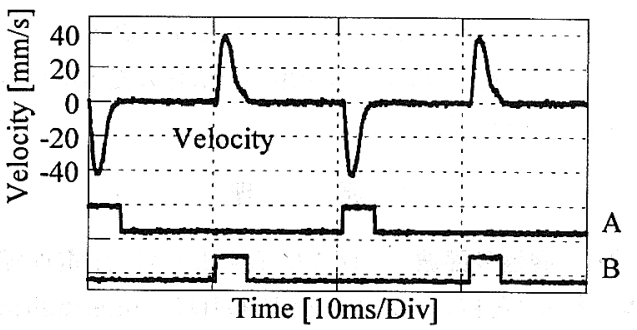

Fig. 7 Steel ball vibration velocity at $50 \mathrm{~Hz}$

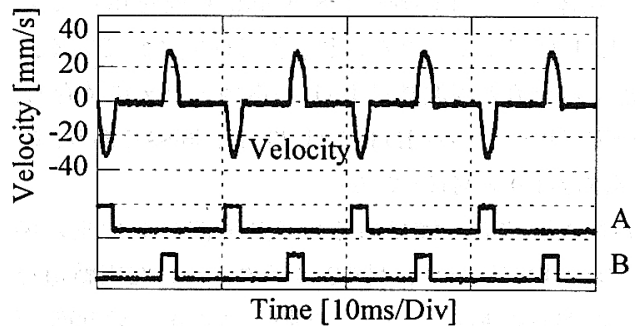

Fig. 8 Steel ball vibration velocity at $100 \mathrm{~Hz}$

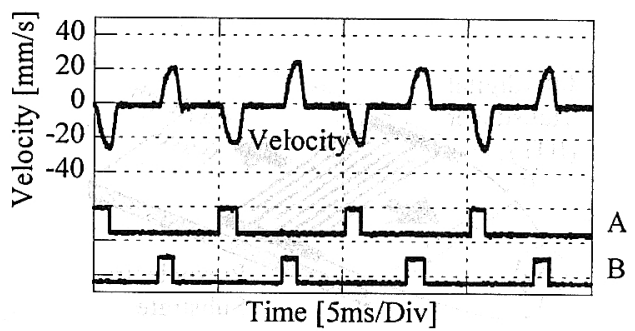

Fig. 9 Steel ball vibration velocity at $200 \mathrm{~Hz}$

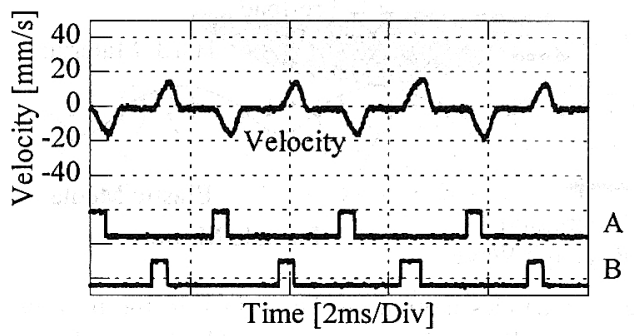

Fig. 10 Steel ball vibration velocity at $400 \mathrm{~Hz}$ 


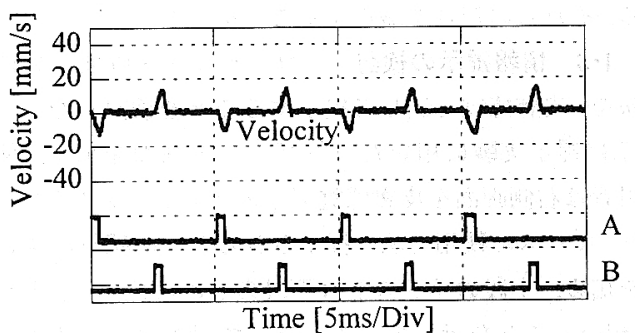

Fig. 11 Steel ball vibration velocity at $200 \mathrm{~Hz}$ (Duty ratio: $1 / 16$ )

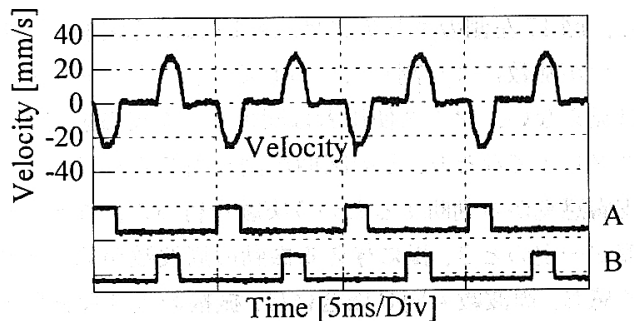

Fig. 12 Steel ball vibration velocity at $200 \mathrm{~Hz}$ (Duty ratio: $3 / 16$ )

設定して, 計測した結果を図 7〜10に示す。図中の矩 波形は，図 4 に示す 2 組のIDT に印加される駆動電 圧の On/Off を示している. 矩形波の周波数を調整す ることで, 鋼球に発生する振動の周波数が制御されて いることがわかる.また，周波数を $200 \mathrm{~Hz}$ とし，矩 形波のディユーティー比を変更した結果を図 11 およ び図 12 に示す. 弾性表面波駆動電圧が印加されてい る時間の長さ，つまりデューティ一比を調整すること で, 鋼球に発生させる振動の強弱が制御されているこ とがわかる.鋼球の振動によるせん断力の交番力が, パッドのゴム膜を介して指皮膚に伝搬して, 皮膚感覚 として受容される。実際に指をのせて使用する際に は，鋼球と振動子の接触圧力が大きくなるため，より 大きなせん断力が得られると考えられる。

\section{4. デモンストレーション}

$4 \cdot 1$ 皮膚感覚ディスプレイマウス 製作した皮 膚感覚ディスプレイユニットを, 図 13 に示すように コンピュータ用マウスの左ボタンに取付けた。ューザ はユニット越しにクリック・ドラッグなどの操作が可 能である.よって，マウスを動かすことでそれをなぞ り動作とし，動作に合わせてパッドに発生する振動を 制御することによって，固体表面をなぞったときの感 覚を擬似的に表現することができる.

$4 \cdot 2$ 粗さ感覚の提示 コンピュータ画面上には, 図 14 に示すように粗さの異なる表面を表現するイラ

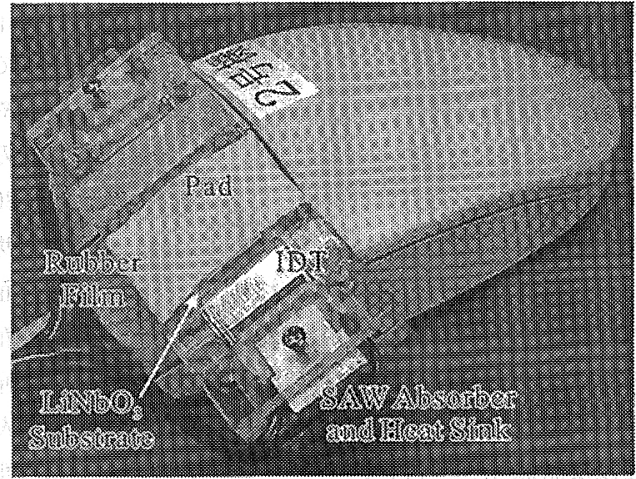

Fig. 13 A tactile display unit installed on a mouse button

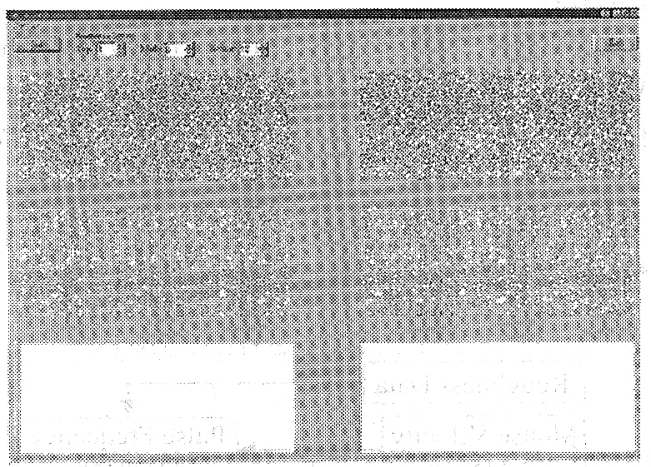

Fig. 14 The view of the computer screen for demonstration of the SAW tactile display mouse

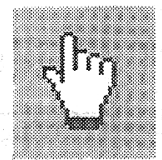

Fig. 15 The mouse pointer for the demonstration

ストが描画されている。図 15 に示すマウスポインタ でイラスト上をなぞると，その動作に基づき皮膚感覚 ディスプレイが制御される.その結果，コンピュータ 画面を直接指でなぞることを擬似的に体験することが できる.

制御には図 16 に示す制御系を用いた。ある粗さを 持った固体表面を，指でなぞったときの感覚で擬似的 に表現するには,なぞり速度と表面粗さによって決定 される周波数の振動を, 指皮膚表面に与えることが有 効である. 粗さ感覚を提示するために，以下のような 手順で制御を行った。マウスの速度 $v_{m}$ を検出し, 粗 さ情報 $k_{r}$ (大きいとより粗い面を表す，単位は m)で 除算して変調周波数を決定する. 決定された周波数情 
報は8ビット整数として PICマイコン (Microchip 社, PIC 16 F 84 A) に入力され，係数 $k_{c}$ が乗算されて 変調周波数が決定される。この係数は，画面解像度や PIC マイコンの制御周期などの影響を補正するための 定数である。決定された周波数において，位相が 180 度異なる二組のパルス波が生成され，2 CHシンセサ イザ(NF WF 1946)に入力されて, $2 \mathrm{CH}$ の弾性表面 波駆動信号に対して On/Off の制御を行う。弾性表面 波駆動信号は高洁波アンプで増幅され、マウストの弾 性表面波皮膚感覚ティスフレイに印加される。弾性表 面波皮虞感覚ディスナレイコーット上のパットは，弾 性表面波伝搬方向に周波数 $f=k_{c} v_{m} / k_{r}$ で振動し，前 述の原理により固体表面をなぞっているような感覚が 得られる。

弾性表面波皮膚感覚ディスプレイへの入力電力 100 W, テューティ一比 $d=1 / 8$ (一定)に枕いて, 実際に 使用してみたところ，なめらかな表面とある粗さを持 った表面を区別することができた．また，上記の提示 実験用画面の 3 種のイラストに対して，kr かから 順に $200,100,50 \mu \mathrm{m}$ 程度となるように設定したとこ

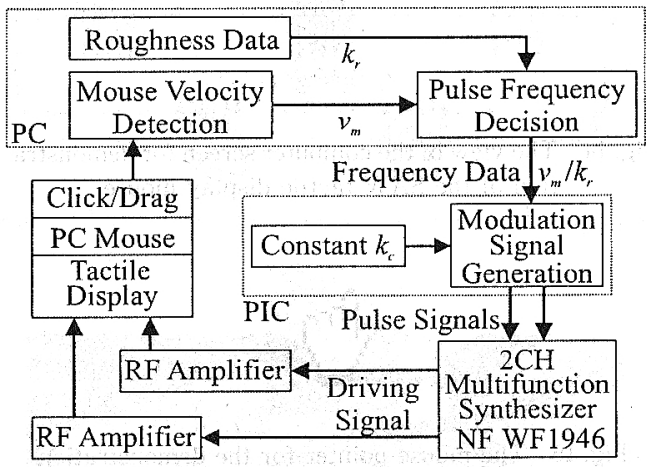

Fig. 16 A tactile display control system for the screen drawn in Fig. 17

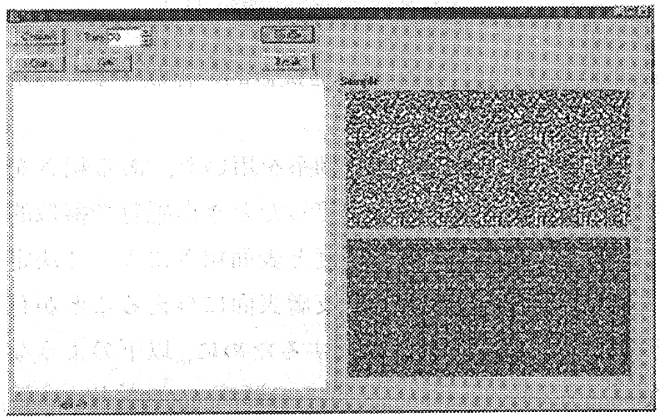

Fig. 17 The view of computer screen for demonstration of information indication
ろ，それらの粗さを識別することができた。

$4 \cdot 3$ 情報提示の検討 コンピュータ画面上の情 報を，皮膚感覚を通して提示することを検討した。図 17 に提示実験に用いたコンピュータ画面を示す。使 用者は右側画面を皮膚感覚ディスプレイマウスでなぞ り，マウスの使用方法と提示される二つの感賞の違い を知る。上段のイラストは下段のものに比べて, より 「粗い」ことを示している.そして，図 18 に示すよう により粗い面が黒色，そうでない面が灰色であると定 義し，使用者にはこの定義に従った情報が提示され る.図 17 左側のエリアには, 図 19 に示す㘠柄のうち 一つが乱数により割り当てられるが，マウス使用者に は見えない。ママウス使用者は同エリアを皮䖉感覚ディ スプレイでなぞり，どの図柄が割り当てられているか 皮膚感覚から判断するという実験を行った。なぞり速 度が一定のとき，指に与える振動の周波数が低いと粗 く感じ, 周波数も同じ場合には，振幅の大きな振動を 与えるとより粗く感じる傾向がある(11). 粗さ感覚を 積極的に利用する観点から，「粗い」注うの感覚を提 示する際には，他方に比べてデューティー比を大き して振幅の大きな振動を与え,より明確な違いを表現 するようにした。

この実験には，図20に示す制御系を用いた。割り

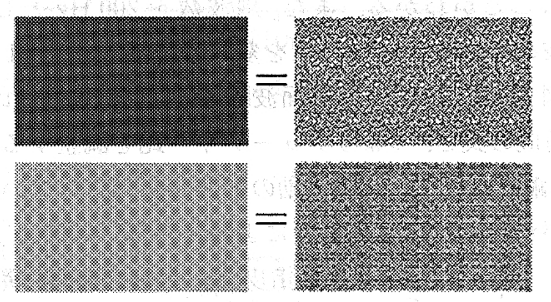

Fig. 18 Tactile expression of gray scale

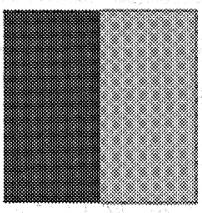

(a)

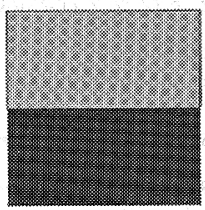

(c)

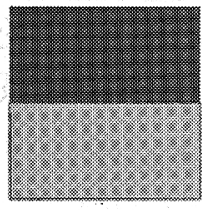

(b)

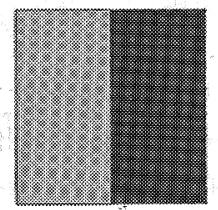

(d)
Fig. 19 Images expressed by the demonstration 


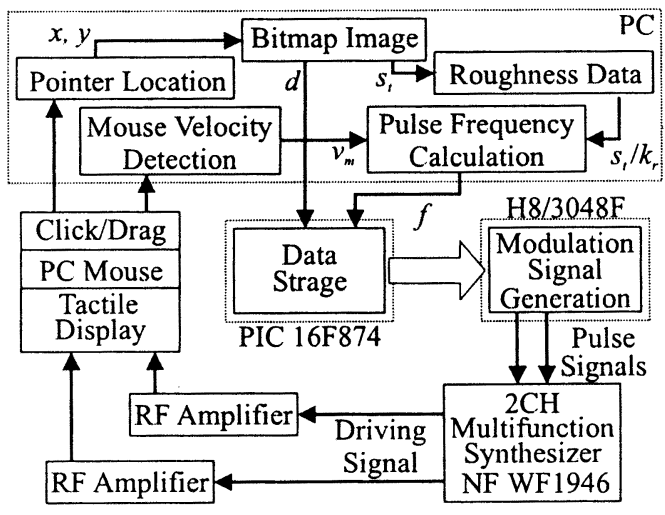

Fig. 20 A tactile display control system for the screen drawn in Fig. 17

当てられている図柄におけるマウスポインタの位置で の色の明度 $s_{t}$ (黒と灰，それぞれ 1 と 2 に設定) と, デ イスプレイから出力すべき振動の強さに関するパラメ ー夕 $d$ (黒と灰，それぞれ $1 / 4$ と $1 / 8$ に設定)を決定す る.ディスプレイから出力される振動の周波数は, $f$ $=k_{c} s_{t} v_{m} / k_{r}$ により決定される.ここで, $k_{c}$ は画面の 解像度を補正する係数である。また， $k_{r}$ を $100 \mu \mathrm{m}$ と した.パラメータ $f$ と $d$ がマイコンに供給され, 周 波数 $f$, デューティー比 $d$ の二相のパルス波が生成さ れる.

10 人の被験者に対し, 図 17 右側のイラストで提示 される皮膚感覚の違いと, 図 18 に示す定義を説明し た後に, ランダムに割り当てられた図柄がどれかを皮 膚感覚により識別してもらう実験を行った。その結 果, 10 人中 8 人が割り当てられた図柄を当てることが できた．マウス操作に伴う皮膚感覚提示により，特定 の情報をユーザに提供するコンピュータインタフェー スの可能性を示すことができた.

\section{5. 結言}

弾性表面波リニアモータを皮膚感覚ディスプレイに 応用し， 2 組の IDT を用いて伝搬方向の異なる二つの
レイリー波を励振して利用し，ある表現粗さをなぞっ たときの感覚を提示する装置を試作した。試作したデ イスプレイをコンピュータ用マウスに取付けて，皮膚 感覚提示実験を行ったところ, 粗さの違いを表現する ことができた．また，視覚的情報を皮膚感覚を通して 提示することを検討し，実験によりその可能性を示し た.

\section{文献}

(1) Fore example, PHANToM, http://www.sensable. com/HapticMASTER, http://www.fcs-cs.com/ robotics/Cyber Force, http://www.immersion.com/

(2) Howe, R. D. et al., Remote Palpation Technology, IEEE Eng. In Medicine and Biology, Vol. 14, No. 3 (1995), pp. 318-323.

(3) Ikei, Y. et al., Texture Presentation by Vibratory Tactile Display, Proceedings of IEEE Virtual Reality Ann. Int'l Symp., (1996-3), pp. 199-205.

(4) Asamura, N. et al., Selectively Stimulating Skin Receptors for Tactile Display, IEEE Computer Graphics and Applications, Vol. 18, No.6 (1998), pp. 32-37.

(5) Watanabe, T. and Fukui, S., A Method for Controlling Tactile Sensation of Surface Roughness Using Ultrasonic Vibration, Proceedings of IEEE Int'l Conf. Advanced Robotics, (1995-9), pp. 1134-1139.

(6) Konyo, M. et al., Tactile Feeling Display for Touch of Cloth Using Soft High Pllymer Gel Actuators, Trans. actions of the Virtual Reality Society of Japan (in Japanese), Vol. 6, No. 4 (2001), pp. 323-328.

(7) Takasaki, M. et al., A Surface Acoustic Wave Tactile Display With Friction Control, Proceedings of IEEE International Workshop on Micro Electro Mechanical Systems, (2001-1), pp. 240-243.

(8) Nara, T. et al., Surface Acoustic Wave Tactile Display, IEEE Computer Graphics and Applications, (2001-11, 12), pp. 56-63.

(9) Takahashi, M. et al., Direct Frictional Driven Surface Acoustic Wave Motor, Proceedings of Transducers '95 and Eurosensors IX, (1995-6), pp. 401-404.

(10) Osakabe, N. et al., Surface acoustic wave linear motor using silicon slider, Proceedings of IEEE International Workshop on Micro Electro Mechanical Systems, (1998-1), pp. 390-395.

(11) Takasaki, M. et al., Active Type Surface Acoustic Wave Tactile Display, Trans. of the Society of Instrument and Control Engineers (in Japanese), Vol. 42, No. 4 (2006), pp. 327-333. 